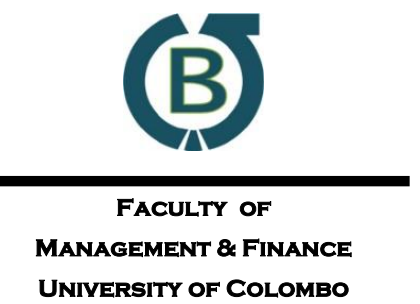

Colombo

Business

Journal

UNIVERSITY OF COLOMBO

INTERNATIONAL JOURNAL OF

THEORY \& PRACTICE

Vol. 10, No. 01, June, 2019

\title{
Earnings Management and Ownership Structure: Evidence from Sri Lanka
}

\author{
Hassan Anwar ${ }^{\mathrm{a}}$, S. Buvanendra ${ }^{\mathrm{a} \bowtie}$ \\ ${ }^{a}$ Department of Finance, University of Colombo, Sri Lanka
}

\begin{abstract}
The main purpose of this study is to examine the impact of ownership structure on earnings management considering listed firms at the Colombo Stock Exchange - Sri Lanka during the period of 2013/14 to 2017/18. Earnings management is measured using discretionary accruals as a proxy based on Kothari, Leone and Wesley (2005) performance adjusted discretionary accrual model, while taking into account the four types of ownership structures, viz, ownership concentration, managerial ownership, institutional ownership and foreign ownership. The study employed pooled OLS regression. The findings of the study reveal that managerial and institutional ownership structures are effective in constraining accruals manipulations. Conversely, foreign ownership is found to have a significantly positive association with earnings management. The outcomes of the paper further widen the literature related to understanding the influences of ownership structure on earnings management in the context of emerging economies.
\end{abstract}

Keywords: Colombo Stock Exchange, Earnings Management, Ownership Structure

Received: Accepted revised version: Published:

08 March 2019 25 May $2019 \quad 30$ June 2019

Suggested citation: Anwar, H. \& Buvanendra, S. (2019). Earnings management and ownership structure: Evidence from Sri Lanka. Colombo Business Journal, (10)1, 44-65.

DOI: http://doi.org/10.4038/cbj.v10i1.42

(C) 2019 The Authors. This work is licenced under a Creative Commons Attribution 4.0 International Licence which permits unrestricted use, distribution, and reproduction in any medium, provided the original work is properly cited.

\bkshanthy@dfn.cmb.ac.lk (iD https://orcid.org/0000-0003-0041-3000 


\section{Introduction}

The globalisation of businesses and financial markets, together with the increase in competition within them, is among the major factors that have elevated the value of quality information (Al-Fayoumi, Abuzayed, \& Alexander, 2010). It is noted by Rusmin (2010) that practices of earnings management decay the faith in financial reporting quality of investors. Consequently, corporate stakeholders have given immense importance to earnings management. However, ensuring the quality of the financial information is a challenging task due to high monitoring cost involved and divergence of interests between shareholders and management (Alves, 2012). As a result, the reported earnings may not always be the real earnings of the business. A number of previous studies examined the effects of earnings management on firms' reported financial statements (Healy, 1985; De Angelo, De Angelo, \& Skinner, 1994; Klein, 2002; Hessayri \& Saihi, 2015). In fact, accounting accruals, by their very nature, give management the discretion of deciding when to report certain earnings (Alzoubi, 2016). Further, it is widely perceived that managers exploit this discretion opportunistically and engage in earnings management practices, for their own personal gain (Watts \& Zimmerman, 1986; Subramanyam, 1996; Guay et al, 1996; Demski, 1998; Hao \& Yao, 2010; Jiraporn, Miller, Yoon, \& Kim, 2008).

On the other hand, in today's corporate world, one could observe a growing dispersion of ownership, which has in turn given rise to separation of ownership and control. According to Jensen and Meckling (1976), separation of ownership and control could lead to a divergence of interest between the owners and the managers a phenomenon commonly known as agency problem. Generally, agency problem arises due to asymmetric information on investment opportunities between owners and managers. As a result, owners have less information to monitor and control the managers' activities. This would finally lead to earnings management practices by managers (Warfield, Wild, \& Wild, 1995). In this contractual situation, characterised by the conflict of interests between shareholders and managers, corporate governance employs different mechanisms that resolve the interests of shareholders and managers (Fama \& Jensen, 1983; Hart, 1995; John \& Senbet, 1998). Subsequently, proper corporate governance mechanisms are highlighted by several amendments of code of best practices - for example, combined code in the UK, Sarbanes-Oxley Act in the USA and Sri Lankan corporate governance code of best practices. However, there is a significant and ongoing argument in the corporate governance literature regarding the apparent relationship between ownership structure and managers' earning management practices (Kazemian \& Sanusi, 2015).

Apart from the above, corporate accounting fraud is evidenced by the devastating high-profile corporate failures such as Enron, WorldCom, Satyam Computers that 
occurred around the globe (Kankanamage, 2015). One of the key causes of the aforementioned corporate failures, and many such others, was the materially misrepresented financial statements via malfeasance accounting practices, due to the lack of monitoring by the stakeholders (Mamo \& Aliaz, 2014; da Costa, 2017). Thus, the regulators throughout the world started to focus on corporate governance mechanisms, especially the ownership structure dimensions to enhance the quality of financial reporting (Al-Fayoumi et al., 2010). However, very few studies in the recent past, especially in emerging economies, have addressed the impact of ownership structure on informativeness of the reported figures (Samarakoon, 1999; Sun, Wang, Wang, \& Zhang, 2013). In case of Sri Lanka, researchers have rarely contributed to the effect of ownership structures on earnings management literature. Kankanamage, (2015) studied the impact of board characteristics on earnings management of nonfinancial listed firms of Sri Lanka, whereas, Wijesinghea and Kehelwalatenna (2017) examined the impact of earnings quality measured through both accruals based measures and real earnings measures on stock returns of listed manufacturing companies alone. To fill the gap in this context, the current study attempts to examine the influence of ownership structures on earnings management measured by discretionary accruals.

\section{Review of Literature}

\section{Theoretical Review}

The extant literature in this area provides several definitions to earnings management. Healy and Wahlen $(1999$, p.368) express that

Earnings management occurs when a manager use(s) judgment in financial reporting and in structuring transactions to alter financial reports to either mislead some stakeholders about the underlying economic performance of the company, or to influence contractual outcomes that depend on reported accounting numbers.

However, this definition is criticised by Ronen and Yaari (2008), due to the lack of clarity between earnings management and earnings manipulation. They offered an alternative definition for earnings management as "a collection of managerial decisions that result in not reporting the true short-term, value maximising earnings as known to management." In addition, Mulford and Comiskey (1996, p. 360) defined earnings management as "active manipulation of accounting results for the purpose of creating an altered impression of business performance".

In fact, reported earnings are composed of cash flow from operations and accruals, thus, managers typically have two options to manage earnings (Joosten, 2012). First type is the real earnings management and Roychowdhury (2006) defined 
it as "departures from normal operational practices, motivated by managers' desire to mislead at least some stakeholders into believing certain financial reporting goals have been met in the normal course of business" (p. 337). The second type is accrualbased earnings management which is the focus of the current study. The main purpose of accounting accruals is to demonstrate the true performance of a firm in a given period. However, reported earnings can be manipulated by the managers when managers have to book accruals for events, such as accounting estimates (e.g. losses from bad debts, asset impairments and salvage value of a non-current asset), that allows for discretion in accounting standards (Joosten, 2012). If the accounting estimates chosen by the managers are biased and do not deliver the true economic performance of the firm, it implies that the managers had engaged in accrual-based earnings management (Healy \& Wahlen, 1999).

As shown in existing literature, researchers have used different measurements to indicate earnings management. Most of the initial proxies have taken accruals as the foundation for calculating the earnings management. Discretionary accrual is a widely used proxy in accounting literature because of its ability to capture the quality of accounting information (Choi, Kim, \& Zhang, 2010). The widely popular model adopted in earnings management literature is Jones model (1991). It is based on the accrual-based earnings management. Later, Dechow, Sloan, and Sweeney (1995), proposed the Modified Jones Model by addressing the weakness in the earlier model. Subsequently, Kothari et al. (2005) suggested that researchers would be able to draw more reliable inferences by using performance-matched discretionary accrual measure. Indeed, Performance-Matched Modified Jones Model (Kothari et al., 2005) is an extension to the commonly used Modified Jones Model (1995). The application of Kothari et al. (2005) model, which is used in the current study, is consistent with many studies on earnings management, such as Rahman and Abdullah (2005), Caramanis and Lenox (2008), Mohd. Ali, Mohd. Salleh, and Hassan (2008), Jouber and Fakhfakh, (2012) and Kankanamage (2015). Therefore, it is more appropriate and justified to investigate the relationship between earnings management and ownership structure measured using discretionary accruals.

The engagement in earnings management leads the way for opportunistic behaviour of managers, resulting in conflict with the stakeholders. Agency conflict is defined by Jensen and Meckling (1976, p.308) as "a contract under which one or more persons (the principal(s)) engage another person (the agent) to perform some services on their behalf which involves delegating some decision-making authority to the agent". However, shareholders do not often know what actions the management can take and which among them would maximise the shareholder wealth (Jensen \& 
Murphy, 1990). Therefore, it is widely believed that managers may often pursue opportunistic behaviour which may conflict with the goals of the shareholders, leading to destruction of wealth of the shareholders (Farouk \& Bashir, 2017). As a result, the managers are motivated to engage in earnings management activities in order to resolve agency problems (Man, Locke, \& Hewa Wellalage, 2018).

\section{Empirical Literature}

\section{Ownership Structures and Earnings Management}

The relationship between ownership structure and earnings management has received an immense attention in financial literature (Yasser, Mamun, \& Hook, 2017). Different dimensions of ownership structure have been tested in the prior studies (Al-Fayoumi et al., 2010; Alzoubi, 2016). In case of concentrated ownership, larger shareholders would be willing to actively monitor and influence the firm to safeguard their fortune (Shleifer \& Vishny, 1997). It would reduce the overall cost of monitoring and discourage the earnings management practices. In other words, the effective monitoring of large shareholders and reduced information asymmetry is expected to reduce the opportunistic behaviour of the managers and hence limit the earnings management. This is supported by previous studies, viz, Ali, Salleh, and Hassan (2008) and Iturriaga and Hoffmann (2005). On the other hand, as the ownership becomes more concentrated, it may cause divergence of interest between large and small shareholders. Large shareholders may employ their control rights to generate personal benefits, expropriating the interests of the minority shareholders (Alves, 2012; Shleifer \& Vishny, 1997). Consequently, large shareholders may interfere on management decisions and encourage managers to involve in earnings management practices to maximise their individual benefits (Alzoubi, 2016). This argument is supported by Kim and Yoon (2008) and de Sousa and Galdi (2016) by providing the evidence of a positive relationship between ownership concentration and earnings management.

Alternatively, managerial ownership is in line with the convergence of interest hypothesis, which suggests that, if management owns a considerable large proportion of the firm's ownership, the market value of the firm should rise (Morck, Shleifer, \& Vishny, 1988). In other words, if managerial ownership increases in the form of firm stock, then they will be more inclined to progressively align their goals with those of the shareholders. Accordingly, managerial ownership is assumed to limit the earnings management practices of the managers. Therefore, the level of earnings management activities is expected to have a significantly negative association with managerial ownership (Alzoubi, 2016; Alves, 2012; Ali et al., 2008; Warfield et al., 1995). 
According to the efficient monitoring hypothesis, institutional ownership is considered as an important governance mechanism. Institutional investors are large shareholders and they might be more capable of monitoring and controlling the management (Shleifer \&Vishny,1997). Therefore, the level of earnings management activities is expected to have a significantly negative association with institutional ownership (Alzoubi, 2016). Conversely, if the institutional investors are more shortterm oriented, their focus will be more towards current earnings rather than long-term earnings. As a result, the behaviour of institutional investors forces managers to meet short-term financial performance, and thereby encouraging managers to engage in earnings management (Alzoubi, 2016). This view is well supported by some group of researchers as well (Lassoued, Attia, \& Sassi, 2017; Ilmas, Tahir, \& Asrar-ul-Haq, 2018).

Beyond the local investors, foreign investors are usually foreign mutual funds or foreign institutional investors, who are perceived to be comparatively more creative in seeking information than the local investors. Additionally, foreign investors are more likely to efficiently process the publicly available information (Jiang \& Kim, 2004). Chung, Ho, and Kim (2004) claimed that companies with a foreign shareholding provide more effective monitoring on managerial discretionary accruals. Therefore, the level of earnings management activities is expected to have a significant negative association with foreign ownership (Alzoubi, 2016).

\section{Firm Factors and Earnings Management}

Apart from ownership structure variables, firm related factors also impact on earnings management. So, to control the variables' influence on earnings management firm factors such as firm size, firm growth, profitability, leverage and audit quality are included as control variables of this study. Firm size is one of the influencing factors over the firms' accruals management decisions (Al-Fayoumi et al., 2010). Dechow and Dichev (2002) found a positive relationship between accruals quality and firm size. Previous studies document the relationship between firm's growth and earnings management and provide mixed results (Guo \& Ma, 2015; Cheng \& Warfield, 2005). Chen, Elder, and Hsieh (2007), and Klein (2002) provide evidence suggesting that firms with higher (lower) profitability have less (more) engagement in earnings management activities. Leverage can have positive association between level of firm's leverage and discretionary accruals (Peasnell, Pope, \& Young, 2005). On the contrary, Chung Firth, and Kim (2002) claimed that companies with high indebtedness will be under close scrutiny by lenders and therefore are less capable of being involved in earnings management. Hence, 
contradicting results are visible from previous literature. So far, empirical studies examining the influence of audit quality on earning management is few. Even among them, there is no consistent result. Companies audited by the Big 4 are assumed to have lower earnings management. This is supported by prior evidences (Chung \& Kallapur, 2003; Francis \& Wang, 2008; Lin \& Hwang, 2010).

As discussed above, in the context of developed countries, earnings management has been studied extensively (Alves, 2012; Habbash, 2013; Spinos, 2013). However, in the case of developing countries like Sri Lanka, only a few studies have been carried out. Kankanamage (2015) found a significant relationship between board size, board composition, board financial expertise and board meetings and earnings management of the Sri Lankan listed firms. While, Wijesinghe and Kehelwalatenna (2017) reveal that there is no significant impact of earnings management on stock returns of listed manufacturing companies in Sri Lanka. It is clear that there are no studies investigating the relationship between earnings management and ownership structure, in the context of Sri Lanka. Therefore, the purpose of the current study is to examine the impact of ownership structure on earnings management in listed companies at the Colombo Stock Exchange (CSE).

Figure 1 shows the conceptual framework which illustrates the relationship between the independent, dependent and control variables considered in the study.

\section{Figure 1: Conceptual Framework}

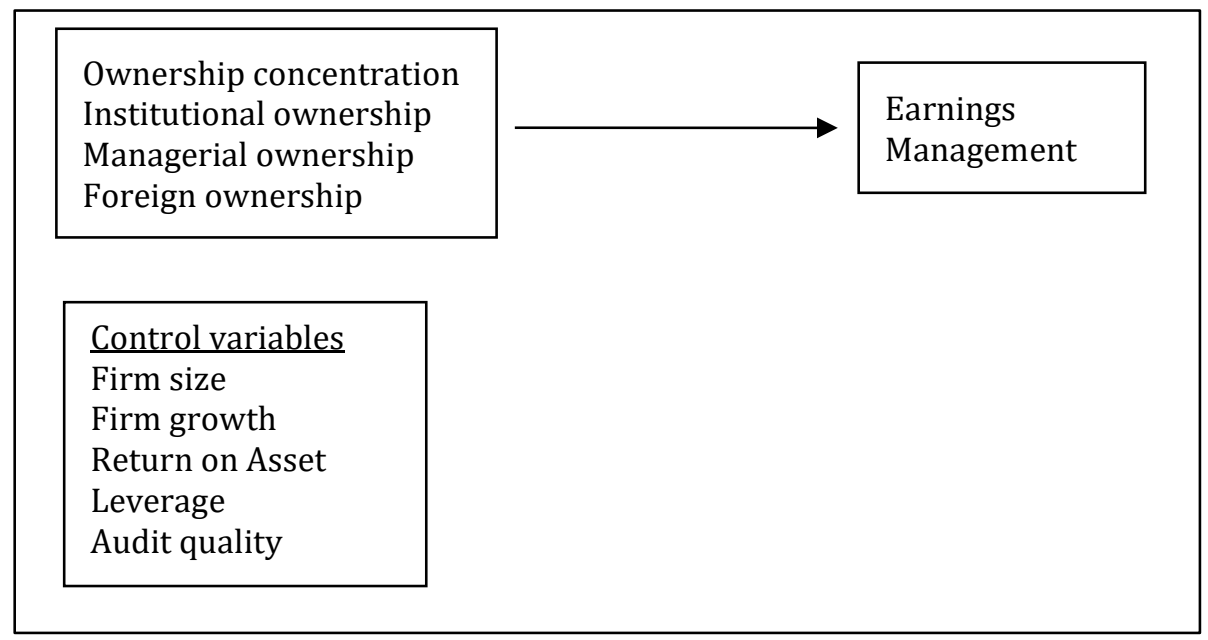




\section{Research Methods}

\section{Data and Sample}

The current study investigates the phenomenon of earnings management and some of its ownership structures in Sri Lanka. Therefore, secondary data of listed firms were manually collected from published annual reports that are publicly available in the CSE data base. The population of the study consists of all the companies listed in CSE from financial year 2012/13 to 2017/18. The financial year 2012/13 was considered, since the data set included some figures calculated using the previous year values. All companies are included in the sample, based on the availability of the data. The financial year started on $1^{\text {st }}$ April and ended on $31^{\text {st }}$ March of the following year. Bank, Finance and Insurance sector companies were eliminated from the sample due to their nature of being highly regulated. Further, companies listed after $1^{\text {st }}$ April 2012, companies with missing financial data and/or inadequate share distribution information and companies having a different year ending other than $31^{\text {st }}$ March were also excluded from the sample. After all these exceptions, the final valid sample for this study was restricted to 71 companies during the period of 2013/14 to 2017/18 with 355 firm years.

\section{Measures of Variables}

Most of the variables used in this study are generally known and their measurement is largely adopted from the existing literature as enunciated by researchers. Definitions of variables used in this study are presented in Table1.

Table 1: Definition of Variables

\begin{tabular}{|c|c|c|c|}
\hline Variable & Acronym & Definition & Evidence \\
\hline \multicolumn{4}{|l|}{ Dependent Variable } \\
\hline Discretionary Accruals & $A B S \_D A C C$ & $\begin{array}{l}\text { Absolute value of discretionary } \\
\text { accruals estimated through the } \\
\text { performance-matched } \\
\text { discretionary accrual model of } \\
\text { Kothari et al. (2005) }\end{array}$ & $\begin{array}{l}\text { Kothari et al } \\
(2005)\end{array}$ \\
\hline \multicolumn{4}{|l|}{ Independent Variables } \\
\hline \multirow[t]{2}{*}{$\begin{array}{l}\text { Ownership } \\
\text { Concentration }\end{array}$} & OWNCON & $\begin{array}{l}\text { Total Percentage of common } \\
\text { stock owned by top five largest } \\
\text { shareholders }\end{array}$ & $\begin{array}{l}\text { Guo and } \\
\text { Ma (2015) }\end{array}$ \\
\hline & & & Contd. \\
\hline
\end{tabular}




\begin{tabular}{|c|c|c|c|}
\hline Variable & Acronym & Definition & Evidence \\
\hline Managerial Ownership & MGROWN & $\begin{array}{l}\text { Total Percentage of common } \\
\text { stock directly owned by Board } \\
\text { of Directors and their family }\end{array}$ & $\begin{array}{l}\text { Abdullah, } \\
\text { Ahmad, and } \\
\text { Roslan, (2012); } \\
\text { Guo and Ma } \\
\text { (2015) }\end{array}$ \\
\hline Institutional Ownership & INSTOWN & $\begin{array}{l}\text { Total Percentage of } \\
\text { common stock held by } \\
\text { institutional shareholders }\end{array}$ & $\begin{array}{l}\text { Abdullah et } \\
\text { al. (2012); } \\
\text { Guo and Ma } \\
(2015)\end{array}$ \\
\hline Foreign Ownership & FOROWN & $\begin{array}{l}\text { Total Percentage of common } \\
\text { stock owned by Foreign } \\
\text { (non-resident) shareholders }\end{array}$ & $\begin{array}{l}\text { Alzoubi, } \\
(2016)\end{array}$ \\
\hline \multicolumn{4}{|l|}{ Control Variables } \\
\hline Firm Size & FSIZE & Natural logarithm of total assets & Alzoubi, (2016) \\
\hline Firm Growth & FGRTH & Year-over-year sales changes & $\begin{array}{l}\text { Habbash (2013), } \\
\text { Al-Fayoumi et al. } \\
(2010)\end{array}$ \\
\hline Return on Asset & $R O A$ & $\begin{array}{l}\text { Net income (Profit after tax) } \\
\text { divided by total assets }\end{array}$ & Alzoubi (2016) \\
\hline Leverage & $L E V$ & $\begin{array}{l}\text { Ratio of total liabilities to total } \\
\text { assets }\end{array}$ & Alves (2012) \\
\hline Audit Quality & $B I G 4$ & $\begin{array}{l}\text { Dummy variable that equals } \\
1 \text { if the auditor is one of the } \\
\text { Big } 4 \text { and } 0 \text { otherwise }\end{array}$ & Alzoubi, (2016) \\
\hline
\end{tabular}

\section{Method of Analysis}

Earnings Management Measure: Regression Based Proxy

The current study also utilises the most commonly used proxy for earnings management in the standard accounting literature (Alves, 2012). That is, Performance-Matched discretionary accrual model proposed by Kothari et al. (2005) is used to estimate the proxy for earnings management. The regression residuals obtained from Equation 1 below, is considered as the discretionary accruals. 


$$
\begin{aligned}
\frac{T A_{i t}}{A_{i t-1}}=\beta_{0}+\beta_{1 i}\left[\frac{1}{A_{i t-1}}\right]+\beta_{2 i}\left[\frac{\Delta R E V_{i t}-\Delta R E C_{i t}}{A_{i t-1}}\right] & +\beta_{3 i}\left[\frac{P P E_{i t}}{A_{i t-1}}\right] \\
& +\beta_{4 i} R O A_{i t}+\varepsilon_{i t}
\end{aligned}
$$

where,

$T A_{i t} \quad$ : Total accruals for the company $i$ in the year $t$

$A_{i t-1} \quad$ : Total assets for the company $i$ at the end of year $t-1$

$\beta_{0} \quad:$ Intercept

$\beta_{1}-\beta_{4}:$ Coefficients

$\triangle R E V_{i t}$ : Change in revenue for the company $i$ between year $t-1$ and $t$

$\triangle R E C_{i t}$ : Change in receivables for the company $i$ between year $t-1$ and $t$

$P P E_{i t} \quad$ : Gross property, plant and equipment for the company $i$ in the year $t$

$R O A_{i t} \quad:$ Return on Assets for the company $i$ in year $t$

$\varepsilon_{i t} \quad:$ Residual for the company $i$ in year $t$.

All variables are scaled by prior year total assets $\left(A_{i t-1}\right)$ to control for heteroscedasticity. Further, total accruals $\left(T A_{i t}\right)$ is considered as a prerequisite to run the regression. Therefore, this study also adopted Cash Flow approach to evaluate total accruals ( $T A$ ) because this method was a contemplated ascendant to the balance sheet method (Hribar \& Collins, 2002). Further, this is consistent with prior studies of Al-Fayoumi et al. (2010), Alves (2012), Idris (2012), and Alzoubi (2016). According to cash flow approach the TA is the difference between net income before extra-ordinary items $(N I)$ and cash flow from operating activities (OCF). The formula is as follows.

$$
T A=N I-O C F
$$

The relationship between earnings management and ownership structures is analysed by using pooled OLS regression in this study as follows.

$$
\begin{aligned}
& A B S_{D A C C}=\beta_{0}+ \beta_{1} \text { OWNCON }+\beta_{2} \text { MGROWN }+\beta_{3} \text { INSTOWN } \\
&+\beta_{4} \text { FOROWN }+\varepsilon_{i} \quad \text { (Model 1) } \\
& \text { ABS } S_{D A C C}=\beta_{0}+\beta_{1} \text { OWNCON }+\beta_{2} \text { MGROWN }+\beta_{3} I N S T O+\beta_{4} \text { FOROWN } \\
&+\beta_{5} \text { FSIZE }+\beta_{6} \text { FGRTH }+\beta_{7} \text { ROA }+\beta_{8} \text { BIG } 4+\varepsilon_{i} \text { (Model 2) }
\end{aligned}
$$


All the variables in regression Models 1 and 2 are as defined in Table 1.

\section{Results and Discussion}

\section{Tests for Data and Models}

\section{Correlation Analysis}

The overall correlation matrix shows the nonexistence of high or perfect pairwise correlations among the regressors that would constitute to multicollinearity. The results of correlation analysis are shown in Appendix 1. There is no symptom for multicollinearity. Variance inflation factor $(V I F)$ is less than 10, affirming the absence of multicollinearity.

\section{Unit Root Test}

Stationarity can be tested by finding out if the time series contains a unit root. Levin-Lin-Chu (LLC) test (Levin, Lin, \& Chu, 2002) was performed for the variables separately at level and the results are presented in Appendix 2. All the variables are significance at $1 \%$ level. This indicates that the variables used in the study are free from unit root issues at level.

\section{Empirical Results of Factors Affecting Earnings Management}

The commonly used tool to test the multivariate analysis is multiple regressions. The study conducted pooled OLS regression analysis to test the impact of selected independent variables on earnings management. Before conducting the analysis, the important assumptions of OLS were checked. The variables follow a univariate normal distribution and it is ensured by the value of skewness that is less than 3 and the value of kurtosis that is less than 10 (Kline, 2004). Descriptive statistics of all selected variables of the study are reported in Appendix 3. The VIF value of all variables of this study is less than 10 and this proves the absences of multicollinearity (O'Brien, 2007). Linearity is also supported in this study since a sufficiently large number of observations (355) are scattered around zero and have a linear pattern. All variables are stationary which is confirmed by unit root test. After ensuring the assumptions, firstly, the analysis examines the possible relationships between earnings management proxy and ownership structure dimensions alone and the results are presented based on Model 1. After that, the same regression is run after adding a set of control variables based on Model 2. Results of Models 1 and 2 are displayed in Table 2. The validity of the models is identified by significant $F$ statistics at $1 \%$ level and the adjusted $R$ squared coefficient of Models 1 and 2 are 0.0665 and 0.2823 , respectively. These suggest that the combination of independent variables explains $6.65 \%$ of the variation of earnings management in Model 1 and $28.23 \%$ of that in 
Model 2. In addition to these, the Durbin-Watson statistics used to identify the presence of autocorrelation also lie between the safe range of 1.5 and 2.5 for both the models.

Table 2: Results of Pooled OLS Regression Analysis for Models 1 and 2

\begin{tabular}{|c|c|c|c|c|}
\hline \multirow[t]{2}{*}{ Variables } & \multicolumn{2}{|c|}{ Model 1} & \multicolumn{2}{|c|}{ Model 2} \\
\hline & Coefficient & $t$-Statistic & Coefficient & $t$-Statistic \\
\hline Constant & 0.08 & $8.691 * * *$ & 0.135 & $6.457 * * *$ \\
\hline OWNCON & -0.003 & -0.342 & -0.017 & -1.126 \\
\hline MGROWN & -0.073 & $-4.424 * * *$ & -0.063 & $-4.066 * * *$ \\
\hline INSTOWN & -0.038 & $-2.458 * *$ & -0.031 & $-2.185 * *$ \\
\hline FOROWN & 0.012 & 1.485 & 0.015 & $1.994 * *$ \\
\hline LNFSIZE & & & -0.005 & $-3.087 * * *$ \\
\hline FGRTH & & & -0.005 & -1.277 \\
\hline$R O A$ & & & 0.322 & $9.931 * * *$ \\
\hline$L E V$ & & & 0.050 & $4.773 * * *$ \\
\hline$B I G 4$ & & & -0.012 & $-2.641 * *$ \\
\hline Adjusted $R^{2}$ & \multicolumn{2}{|c|}{0.0665} & \multicolumn{2}{|c|}{0.2823} \\
\hline$F$-statistic & \multicolumn{2}{|c|}{$7.304 * * *$} & \multicolumn{2}{|c|}{$16.474 * * *$} \\
\hline Durbin-Watson & \multicolumn{2}{|c|}{1.72} & \multicolumn{2}{|c|}{1.88} \\
\hline VIF & \multicolumn{2}{|c|}{1.071} & \multicolumn{2}{|c|}{1.393} \\
\hline
\end{tabular}

Note: $* * *$ and $* *$ denote significance levels $p<0.01$ and $p<0.05$, respectively.

According to the results of the analysis, among the measure of ownership structures, institutional ownership (INSTOWN) and managerial ownership $(M G R O W N)$ are statistically negatively significant at $5 \%$ and $1 \%$ levels respectively in both models. This indicates that increase in institutional and managerial ownership helps to reduce the earnings management among Sri Lankan listed firms. The results are supportive of active monitoring hypothesis advocated by Shleifer and Vishny (1997) and incentive alignment effect discussed by Jensen and Meckling (1976). It shows that institutional investors are actively monitoring the wealth they have invested, which is mostly a large amount compared to individual investors. At the same time, the findings exhibit that the directors are also aligning their interests with that of the shareholders as their ownership increases. As such, they are ensuring that the quality of financial reports published by the company is maintained. These 
findings match with Alzoubi (2016) and Ali et al. (2008) which found a negatively significant association between institutional and managerial ownership in Jordan and Malaysia, respectively.

Contrarily, the foreign ownership (FOROWN) variable was observed to have a positive coefficient in both models. However, unlike in Model 1, FOROWN is statistically positively significant with earnings management in Model 2. There are two possible explanations for this association. Firstly, this could happen if the foreign investors are at a significant information disadvantage and as a result have to incur high monitoring costs (Ryu \& Ji, 2015). This would encourage managerial opportunistic behaviour when foreign ownership is on the rise. The second possible explanation is that, lower earnings management might not be among the factors that attracts foreign investors. In fact, firm performance is the most attractive factor to foreign investors, in turn, there might be a tendency among foreign investors to invest in the firms reporting better financial figures. This would encourage managers to engage in earnings management practices in order to make the foreign investors happier (Ryu \& Ji, 2015).

On other hand, the coefficient of ownership concentration (OWNCON) is negative, but not statistically significant in both models. Therefore, it can be said that there is no adequate statistical evidence to prove that ownership concentration helps to mitigate the earnings management activities of managers in Sri Lanka. This result is consistent with Ryu and Ji (2015), who documented similar results for a sample of Korean firms. Idris (2012) and Al-Fayoumi et al. (2010) also found a statistically insignificant result in Jordan.

With regard to the control variables except for the firm growth (FGRTH) all other variables are significant at $1 \%$ or $5 \%$. The insignificant result for FGRTH suggests that there is no statistical evidence that firm growth helps to limit earnings management in Sri Lankan listed firms. Firm Size ( LNFSIZE) is negatively significant at $1 \%$ level. As suggested by Dechow and Dichev (2002), as the firms evolve in size, they become more organised and have more stable and predictable operations and thereby more stable accruals. This finding is consistent with Alzoubi (2016) and Idris (2012). Similarly, the audit quality (BIG4) dummy variable has a negative coefficient which is statistically significant at 5\% level. It implies that Big 4 auditors are likely to disclose anomalies and material errors and thereby discouraging earnings management by using opportunistic behaviour of the managers in Sri Lankan listed firms. This result is congruent with the findings of Alzoubi (2016). Contrary to these 
findings, the Profitability $(R O A)$ and Leverage ( $L E V$ ) were found to have positive coefficients which are significant at $1 \%$ level. The positive association between $R O A$ and earnings management means that the more profitable companies are, the more discretionary accruals are prevailing in the firm. Managers of profitable firms might be encouraged to engage in earnings management in order to keep their records high and to be more competitive in the managerial labour market. This finding is supported by Al-Fayoumi et al. (2010) and Ryu and Ji (2015). Further, the positive association between leverage and earnings management found in Sri Lankan firms depicts that the companies with more debt are experiencing financial distress. It suggests that managers of financially distressed firms are engaging in earnings management probably to avoid violation of debt covenants, and hence renegotiation of lending contracts (Idris, 2012).

\section{Conclusion, Implications and Further Research}

This study investigated the impact of ownership structure on accrual-based earnings management among the firms listed in the Colombo Stock Exchange (CSE). It is based on the data of 71 companies listed in CSE during the financial years 2013/14 to 2017/18. In sum, the findings of this study highlight the significance of ownership structure, especially managerial ownership and institutional ownership, in curbing the likelihood of earnings management in Sri Lanka. In other words, it indicates that both managerial ownership and institutional ownership help to enhance the quality and value relevance of reported financial information. Opposed to the expectation, foreign ownership was found to have a positive and statistically significant association with earnings management. The reason could be that foreign investors are expected short term financial results; thus, they may not limit the earnings management discretions by managers in Sri Lankan firms. In addition to this, except firm growth all other selected firm factors, viz firm size, profitability, leverage and audit quality have significant effects either positively or negatively on earnings management in Sri Lankan firms.

The conclusions of this research paper impart a multitude of implications for listed firms operating in Sri Lanka, and other emerging market economies, particularly in South Asia. The findings of the study recommend that both regulators and policy makers whose role is protecting the financial reporting system need to consider different ownership structures and the different repercussions they have on earnings management measured using discretionary accruals. Further, the results of this study advocated that the existence of managerial and institutional ownership structures do not encourage earnings manipulations and it enhances financial 
reporting quality. Additionally, the positive influence of foreign ownership on earnings management implies the requirement of proper monitoring and scrutiny over financial reporting information of such firms. Finally, the investors of the firms could take their future investment decisions by considering that ownership structures play a monitoring role and affect earnings management as well as financial reporting quality. This study only focuses on accrual-based earnings management, while there is another type of earnings management known as real activity-based earnings management as proposed by Roychowdhury (2006). Therefore, as a final thought, future research could look at the impact of ownership structure on real activity-based earnings management.

\section{Declaration of Conflicting Interests}

The authors declared no potential conflicts of interest with respect to the research, authorship, and publication of this article.

\section{References}

Abdullah, N. M. H., Ahmad, Z., \& Roslan, S. (2012). The influence of ownership structure on the firm's dividend policy based Lintner Model. International Review of Business Research Papers, 8(6), 71-88.

Al-Fayoumi, N., Abuzayed, B., \& Alexander, D. (2010). Ownership structure and earnings management in emerging markets: The case of Jordan. International Research Journal of Finance and Economics, 38(1), 28-47.

Ali, S. M., Salleh, N. M., \& Hassan, M. S. (2008). Ownership structure and earnings management in Malaysian listed companies: The size effect. Asian Journal of Business and Accounting, 1(2), 89-116.

Alves, S. (2012). Ownership structure and earnings management: Evidence from Portugal. Australasian Accounting, Business and Finance Journal, 6(1), 57-74.

Alzoubi, E.S.S. (2016). Ownership structure and earnings management: Evidence from Jordan. International Journal of Accounting \& Information Management, 24(2), 135-161. doi:10.1108/IJAIM-06-2015-0031

Caramanis, C., Lennox, C. (2008). Audit effort and earnings management. Journal of Accounting and Economics, 45(1), 116-138. doi:10.1016/j.jacceco.2007.05.002

Chen, K. Y., Elder, R. J., \& Hsieh, Y.-M. (2007). Corporate governance and earnings management: The implications of corporate governance best-practice principles for Taiwanese listed companies. Journal of Contemporary Accounting \& Economics, 3(2), 73-105. doi:10.1016/S1815-5669(10)70024-2

Cheng, Q., \& Warfield, T. D. (2005). Equity incentives and earnings management. The Accounting Review, 80(2), 441-476. doi:10.2308/accr.2005.80.2.441 
Choi, J-H., Kim, J-B., \& Zang, Y. (2010). Do abnormally high audit fees impair audit quality? Auditing: A Journal of Practice \& Theory,29(2), 115-140. doi:10.2308/aud.2010.29.2.115

Chung, H., \& Kallapur, S. (2003). Client importance, nonaudit services, and abnormal accruals. The Accounting Review, 78(4), 931-955. doi:10.2308/accr.2003. $\underline{78.4 .931}$

Chung, R., Firth, M., \& Kim, J.-B. (2002). Institutional monitoring and opportunistic earnings management. Journal of Corporate Finance, 8(1), 29-48. doi:10.1016/S0929-1199(01)00039-6

Chung, R., Ho, S., \& Kim, J.-B. (2004). Ownership structure and the pricing of discretionary accruals in Japan. Journal of International Accounting, Auditing and Taxation, 13(1), 1-20. doi:10.1016/j.intaccaudtax.2004.02.003

da Costa, A. P. P. (2017). Corporate governance and fraud: Evolution and considerations. In L. Emeagwali (Ed.), Corporate governance and strategic decision making. Intech Open. doi:10.5772/intechopen.68489

DeAngelo, H., DeAngelo, L., \& Skinner, D. J. (1994). Accounting choice in troubled companies. Journal of Accounting and Economics, 17(1-2), 113-143. doi:10.1016/0165-4101(94)90007-8

Dechow, P. M., \& Dichev, I. D. (2002). The quality of accruals and earnings: The role of accrual estimation errors. The Accounting Review, 77(s-1), 35-59. doi:10.2308/accr.2002.77.s-1.35

Dechow, P. M., Sloan, R. G., Sweeney, A. P. (1995). Detecting earnings management. The Accounting Review, 70(2), 193-225.

Demski, J. S. (1998). Performance measure manipulation. Contemporary Accounting Research, 15(3), 261-285. doi:10.1111/j.1911-3846.1998.tb00560.x

de Sousa, E. F., \& Galdi, F. C. (2016). A relação entre a concentração de propriedade e a qualidade do lucro: Evidencias do BrasilLa relación entre la concentración de la propiedad y la calidad de los beneficios en empresas brasileñas [The relationship between equity ownership concentration and earnings quality: Evidence from Brazil]. Revista de Administração, 51(4), 331-341. doi:10.1016/ j.rausp.2016.07.006.

Fama, E. F., \& Jensen, M. C. (1983). Separation of ownership and control. The Journal of Law and Economics, 26(2), 301-325.

Farouk, M. A., \& Bashir, N. M. (2017). Ownership structure and earnings management of listed conglomerates in Nigeria. Indian-Pacific Journal of Accounting and Finance, 1(4), 42-54. 
Francis, J. R., \& Wang, D. (2008). The joint effect of investor protection and big 4 audits on earnings quality around the world. Contemporary Accounting Research, 25(1), 157-191. doi:10.1506/car.25.1.6

Guay, W. R., Kothari, S. P., \& Watts, R. L. (1996). A market-based evaluation of discretionary accrual models. Journal of accounting research, 34, 83-105. doi: $10.2307 / 2491427$

Guo, F., \& Ma, S. (2015). Ownership characteristics and earnings management in China. The Chinese Economy, 48(5), 372-395. doi:10.1080/10971475.2015.1067086

Habbash, M. (2013). Earnings management, audit committee effectiveness and the role of blockholders ownership: Evidence from UK large firms. International Journal of Business Governance and Ethics, 8(2), 155-180. doi:10.1504/IJBGE.2013.054418

Hao, Q., \& Yao, L. J. (2010). An explanation for earnings management: Opportunistic or signalling? The Journal of Theoretical Accounting Research, 5(2), 82-95.

Hart, O. (1995). Corporate governance: Some theory and implications. The Economic Journal, 105(430), 678-689. doi:10.2307/2235027

Healy, P. M. (1985). The effect of bonus schemes on accounting decisions. Journal of Accounting and Economics, 7(1-3), 85-107. doi:10.1016/0165$\underline{4101(85) 90029-1}$

Healy, P. M., \& Wahlen, J. M. (1999). A review of the earnings management literature and its implications for standard setting. Accounting Horizons, 13(4), 365-383. doi:10.2308/acch.1999.13.4.365

Hessayri, M., \& Saihi, M. (2015). Monitoring earnings management in emerging markets: IFRS adoption and ownership structure. Journal of Economic and Administrative Sciences, 31(2), 86-108. doi:10.1108/JEAS-11-2014-0029

Hribar, P., \& Collins, D. W. (2002). Errors in estimating accruals: Implications for empirical research. Journal of Accounting Research,40(1), 105-134. doi:10.1111/1475-679X.00041

Idris, M. I. (2012). The impact of ownership structure and external audit on accruals and real activities earnings management in Jordan (Unpublished doctoral dissertation). University of Gloucestershire.

Ilmas, F., Tahir, S., \& Asrar-ul-Haq, M. (2018). Ownership structure and debt structure as determinants of discretionary accruals: An empirical study of Pakistan. Cogent Economics \& Finance, 6(1), 1-27. doi:10.1080/23322039. $\underline{2018.1439254}$

Iturriaga, F. J. L., \& Hoffmann, P. S. (2005). Earnings management and internal 
mechanisms of corporate governance: Empirical evidence from Chilean firms. Corporate Ownership \& Control, 3(1), 17-29. doi:10.22495/cocv3i1p2

Jensen, M. C., \& Meckling, W. H. (1976). Theory of the firm: Managerial behavior, agency costs and ownership structure. Journal of Financial Economics, 3(4), 305-360. doi:10.1016/0304-405X(76)90026-X

Jensen, M. C., \& Murphy, K. J. (1990). Performance pay and top-management incentives. Journal of Political Economy, 98(2), 225-264. doi:10.1086/261677

Jiang, L., \& Kim, J.-B. (2004). Foreign equity ownership and information asymmetry: Evidence from Japan. Journal of International Financial Management \& Accounting, 15(3), 185-211. doi:10.1111/j.1467-646X.2004.00107.x

Jiraporn, P., Miller, G. A., Yoon, S. S., \& Kim, Y. S. (2008). Is earnings management opportunistic or beneficial? An agency theory perspective. International Review of Financial Analysis, 17(3), 622-634. doi:10.1016/j.irfa.2006.10.005

John, K., \& Senbet, L. W. (1998). Corporate governance and board effectiveness. Journal of Banking \& Finance, 22(4), 371-403. doi:10.1016/ $\underline{\text { S0378-4266(98)00005-3 }}$

Jones, J. J. (1991). Earnings management during import relief investigations. Journal of Accounting Research, 29(2), 193-228. doi:10.2307/2491047

Joosten, C. (2012). Real earnings management and accrual-based earnings management as substitutes (Unpublished master's thesis). Tilburg University, Tilburg.

Jouber, H., \& Fakhfakh, H. (2012). Earnings management and board oversight: An international comparison. Managerial Auditing Journal,27(1), 66-86. doi: $10.1108 / 02686901211186108$

Kankanamage, C. A. (2015). The relationship between board characteristics and earnings management: Evidence from Sri Lankan listed companies. Kelaniya Journal of Management, 4(2), 36-43.

Kazemian, S., \&Sanusi, Z. M. (2015). Earnings management and ownership structure. Procedia Economics and Finance, 31, 618-624. doi:10.1016/S22125671(15)01149-1

Kim, H. J., \& Yoon, S. S. (2008). The impact of corporate governance on earnings management in Korea. Malaysian Accounting Review, 7(1), 43-59.

Klein, A. (2002). Audit committee, board of director characteristics, and earnings management. Journal of Accounting and Economics, 33(3), 375-400. doi:10.1016/S0165-4101(02)00059-9

Kline, R. B. (2004). Principles and practice of structural equation modelling ( $2^{\text {nd }}$ ed.). New York: Guilford Press. 
Kothari, S. P., Leone, A. J., \& Wasley, C. E. (2005). Performance matched discretionary accrual measures. Journal of Accounting and Economics, 39(1), 163-197. doi:10.1016/j.jacceco.2004.11.002

Lassoued, N., Attia, M. B. R., \& Sassi, H. (2017). Earnings management and ownership structure in emerging market: Evidence from banking industry. Managerial Finance, 43(10), 1117-1136. doi:10.1108/MF-11-2015-0312

Levin, A., Lin, C.-F., \& Chu, C.-S. J. (2002). Unit root tests in panel data: Asymptotic and finite-sample properties. Journal of Econometrics, 108(1), 1-24. doi:10.1016/S0304-4076(01)00098-7

Lin, J. W., \& Hwang, M. I. (2010). Audit quality, corporate governance, and earnings management: A meta-analysis. International Journal of Auditing, 14(1), 57-77. doi:10.1111/j.1099-1123.2009.00403.x

Mamo, J. \& Aliaz, A. (2014). Accounting manipulation and its effects in the financial statements of Albanian entities. Interdisciplinary Journal of Research and Development, 1(2), 55-60.

Man, Y., Locke, S., \& Hewa Wellalage, N. (2018). Earnings management and agency costs: Evidence from China. Paper presented at the $9^{\text {th }}$ Conference on Financial Markets and Corporate Governance (FMCG). Retrieved from https://papers.ssrn.com/sol3/papers.cfm?abstract_id=3100692

Mohd. Ali, S., Mohd. Salleh, N., \& Hassan, M.S. (2008). Ownership structure and earnings management in Malaysian listed companies: The size effect. Asian Journal of Business and Accounting, 1(2), 89-116

Morck, R., Shleifer, A., \& Vishny, R. W. (1988). Management ownership and market valuation: An empirical analysis. Journal of Financial Economics, 20 (1-2), 293315. doi:10.1016/0304-405X(88)90048-7

Mulford, C., \&Comiskey, E. (1996). Financial warnings: Detecting earning surprises, avoiding business troubles, implementing corrective strategies $\left(1^{\text {st }}\right.$ ed.). John Wiley \& Sons Inc.

O'Brien, R. M. (2007). A caution regarding rules of thumb for variance inflation factors. Quality \&Quantity, 41(5), 673-690. doi:10.1007/s11135-006-9018-6

Peasnell, K. V., Pope, P. F., \& Young, S. (2005). Board monitoring and earnings management: Do outside directors' influence abnormal accruals? Journal of Business Finance \& Accounting, 32(7-8), 1311-1346. doi:10.1111/j.0306686X.2005.00630.x

Rahman, R. A., \& Abdullah W. R. W. (2005). The new issues puzzle in Malaysia: Performance and earnings management. Journal of Financial Reporting and Accounting,3(1), 91-110. doi:10.1108/19852510580000339 
Ronen, J., \& Yaari, V. (2008). Earnings management: Emerging insights in theory, practice, and research. New York: Springer.

Roychowdhury, S. (2006). Earnings management through real activities manipulation. Journal of Accounting and Economics,42(3), 335-370. doi:10.1016/j.jacceco.2006.01.002

Rusmin, R. (2010). Auditor quality and earnings management: Singaporean evidence. Managerial Auditing Journal, 25(7), 618-638. doi:10.1108/02686901011061324

Ryu, Y. R., \& Ji, S. H. (2015). A Study on the impact of foreign investors on earnings management: Using investment horizons of foreign investors Annual Report of the International Accounting Research Society No. 1 Fiscal Year 2015).

Samarakoon, L. P. (1999). The ownership structure of Sri Lankan companies. Sri Lankan Journal of Management, 4, 143-171.

Shleifer, A., \& Vishny, R. W. (1997). A survey of corporate governance. The Journal of Finance, 52(2), 737-783. doi:10.1111/j.1540-6261.1997.tb04820.x

Spinos, E. (2013). Managerial ownership and earnings management in times of financial crisis: Evidence from the USA. (Unpublished master's thesis). School of Economics, Erasmus University.

Subramanyam, K. R. (1996). The pricing of discretionary accruals. Journal of Accounting and Economics,22(1-3), 249-281. doi:10.1016/S01654101(96)00434-X

Sun, Y., Wang, W., Wang, X., \& Zhang, W. (2013). Shareholder activism and earnings management incentives: An empirical examination of shareholder proposals in the United States. Journal of International Financial Management \& Accounting, 24(3), 234-260. doi:10.1111/jifm.12010

Warfield, T. D., Wild, J. J., \& Wild, K. L. (1995). Managerial ownership, accounting choices, and informativeness of earnings. Journal of Accounting and Economics, 20(1), 61-91. doi:10.1016/0165-4101(94)00393-J

Watts, R. L. \& Zimmerman, J. L. (1986). Positive Accounting theory. Englewood Cliffs, NJ: Prentice Hall.

Wijesinghe, M. R. P., \& Kehelwalatenna, S. (2017). The impact of earnings quality on the stock returns of listed manufacturing companies in the Colombo stock exchange. Colombo Business Journal8(2),68-89.

Yasser, Q. R., Mamun, A. A., \& Hook, M. (2017). The impact of ownership structure on financial reporting quality in the east. International Journal of Organizational Analysis, 25(2), 178-197. doi:10.1108/IJOA-08-2015-0894 
Appendix 1: Correlation Analysis

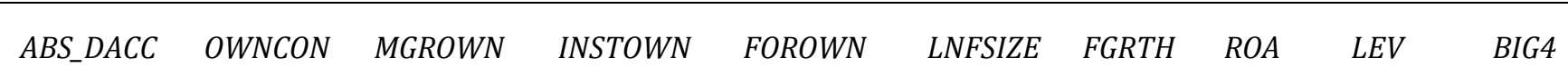

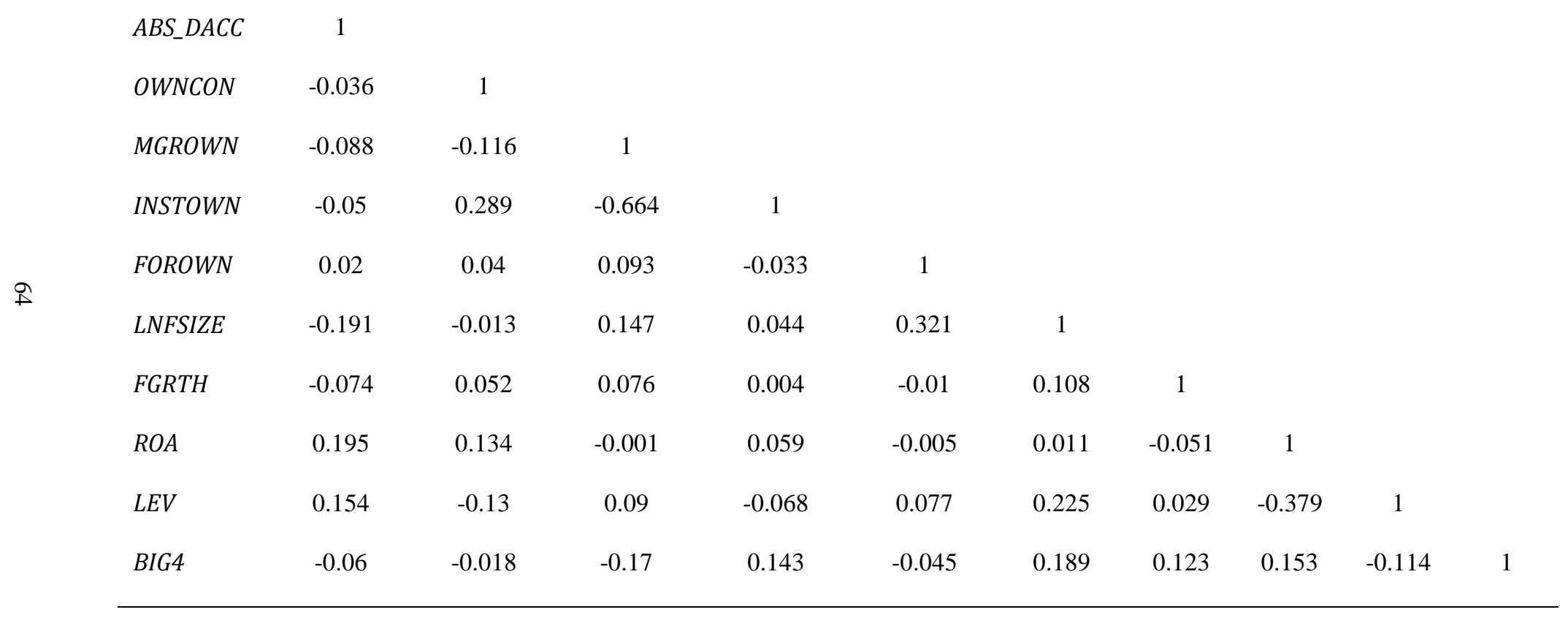


Appendix 2: Unit Root Analysis

\begin{tabular}{ll}
\hline Variables & $\boldsymbol{t}$-Statistics \\
\hline ABS_DACC & $-26.926 * * *$ \\
OWNCON & $-56.122 * * *$ \\
MGROWN & $-1899.670 * * *$ \\
INSTOWN & $-985.327 * * *$ \\
FOROWN & $-967.445 * * *$ \\
LNFSIZE & $-5.777 * * *$ \\
FGRTH & $-25.301 * * *$ \\
ROA & $-13.468 * * *$ \\
LEV & $-12.274 * * *$ \\
\hline
\end{tabular}

Note: $\quad * * *$ denotes significance level $p<0.01$.

Appendix 3: Descriptive Statistics of the Variables Used in the Study

\begin{tabular}{|c|c|c|c|c|c|c|c|}
\hline Variables & Mean & Median & Maximum & Minimum & $\begin{array}{l}\text { Standard } \\
\text { deviation }\end{array}$ & Skewness & Kurtosis \\
\hline$D A C C$ & 0.009 & -0.003 & 0.448 & -0.247 & 0.079 & 1.055 & 7.385 \\
\hline$A B S \_D A C C$ & 0.056 & 0.040 & 0.448 & 0.000 & 0.055 & 2.568 & 10.590 \\
\hline OWNCON & 0.777 & 0.790 & 0.98 & 0.434 & 0.120 & -0.865 & 5.513 \\
\hline MGROWN & 0.088 & 0.004 & 0.706 & 0.000 & 0.166 & 2.331 & 7.606 \\
\hline INSTOWN & 0.735 & 0.829 & 0.982 & 0.000 & 0.244 & -1.531 & 4.394 \\
\hline FOROWN & 0.130 & 0.027 & 0.920 & 0.000 & 0.216 & 2.152 & 6.941 \\
\hline LNFSIZE & 15.812 & 15.761 & 19.162 & 12.699 & 1.391 & 0.181 & 2.391 \\
\hline FGRTH & 0.091 & 0.078 & 3.353 & -0.925 & 0.308 & 2.122 & 10.122 \\
\hline$R O A$ & 0.056 & 0.049 & 0.300 & -0.114 & 0.058 & 0.697 & 5.333 \\
\hline$L E V$ & 0.370 & 0.350 & 0.954 & 0.009 & 0.214 & 0.345 & 2.24 \\
\hline BIG4 & 0.915 & 1.000 & 1.000 & 0.000 & 0.279 & -2.987 & 9.925 \\
\hline
\end{tabular}

Note: $\quad$ DACC $=$ standard value of discretionary accruals; $A B S_{-} D A C C=$ absolute value of discretionary accruals; $O W N C O N=$ proportion of common stock held by largest five shareholders; MGROWN = proportion of common stock held directors and their immediate family; INSTOWN $=$ proportion of common stock held institutional shareholders; FOROWN = proportion of common stock held foreign shareholders; LNFSIZE = natural logarithm of total assets; FGRTH = year-on-year change in total revenue; $R O A=$ return on assets; $L E V=$ total liabilities scaled by total assets; BIG4 = a dummy variable that equals 1 if the firm is being audited by a Big 4 auditors. 